\title{
A checklist of the non-acarine arachnids (Chelicerata: Arachnida) of the Ndumo Game Reserve, Maputaland, South Africa
}

\author{
C. R. HAdDad, A. S. DippenaAR-Schoeman and W. Wesolowska
}

Haddad, C.R., A.S. Dippenaar-Schoeman and W. Wesołowska. 2006. A checklist of the non-acarine arachnids (Chelicerata: Arachnida) of the Ndumo Game Reserve, Maputaland, South Africa. Koedoe 49(2): 1-22. Pretoria. ISSN 0075-6458.

\begin{abstract}
Arachnids (Chelicerata: Arachnida) were collected in the Ndumo Game Reserve (Maputaland, South Africa) during 11 collecting trips in the period 2000-2006. Sampling was undertaken by various methods in eight broad habitat types: Acacia tortilis savanna; Acacia xanthophloea (fever tree) forests; deciduous broadleaf woodland; Ficus (wild fig tree) forests; floodplain vegetation; riparian forest; sand forest; and subtropical bush. In total, 457 species of arachnids were collected, representing six orders, 59 families and 240 determined genera. The most diverse order was the Araneae (46 families, 431 spp.), followed by the Pseudoscorpiones (6 families, $12 \mathrm{spp}$.), Scorpiones (3 families, 8 spp.), Opiliones ( 2 families, 3 spp.), Solifugae (1 family, 2 spp.) and Amblypygi (a single species). The most diverse families all belonged to the Araneae: Salticidae (82 spp.), Thomisidae (56 spp.) and Araneidae (38 spp.). The spider diversity is the highest recorded from any protected area in South Africa so far, and represents approximately $22 \%$ of the country's spider fauna. The habitat and guild associations of each species are provided.
\end{abstract}

Key words: Arachnida, Araneae, conservation, diversity, habitats, Ndumo Game Reserve, South African National Survey of Arachnida (SANSA).

C. R. Haddad, Department of Zoology \& Entomology, University of the Free State, P.O. Box 339, Bloemfontein 9300, South Africa; A. S. Dippenaar-Schoeman, ARC-Plant Protection Research Institute, Private Bag X134, Queenswood 0121, South Africal Department of Zoology \& Entomology, Faculty of Natural and Agricultural Sciences, University of Pretoria, Pretoria, 0002 South Africa; W. Wesolowska, Zoological Institute, Wrocław University, Sienkiewicza 21, PL-50335, Wrocław, Poland.

\section{Introduction}

The Ndumo Game Reserve (NGR) is situated in the western parts of the Maputaland bioregion in northern KwaZulu-Natal, South Africa (Van Wyk \& Smith 2001). Despite its relatively small size it is one of South Africa's most attractive reserves, forming a RAMSAR site protecting several wetland and riparian ecosystems (Ramsar 2001). At NGR, a combination of subtropical climate and rich habitat diversity provide conditions conducive for impressive species diversity. Although several vertebrate and plant taxa have been well studied (e.g. Pooley 1965; Dixon 1966; De Moor et al. 1977), the diversity of invertebrates is poorly known (Haddad 2003), and consequently, there is great potential for invertebrate research in this part of southern Africa.

Relative to other parts of South Africa, few surveys have been conducted on the arachnid fauna of the KwaZulu-Natal Province, and many distribution records are limited to species descriptions (Lawrence 1937a, 1937b, 1938, 1942a, 1942b, 1952). Lawrence et al. (1980) studied the arachnid fauna of Maputaland, with the emphasis on the fauna of the eastern shore of Lake Sibaya. Van der Merwe et al. (1996) investigated spiders in indigenous forests and pine plantations at the Ngome State Forest, while Dippenaar-Schoeman \& Wassenaar (2002, in press) studied the fauna of rehabilitated coastal dune forests near Richards Bay. Most recently, Honiball et al. (in prep.) examined diversity patterns 


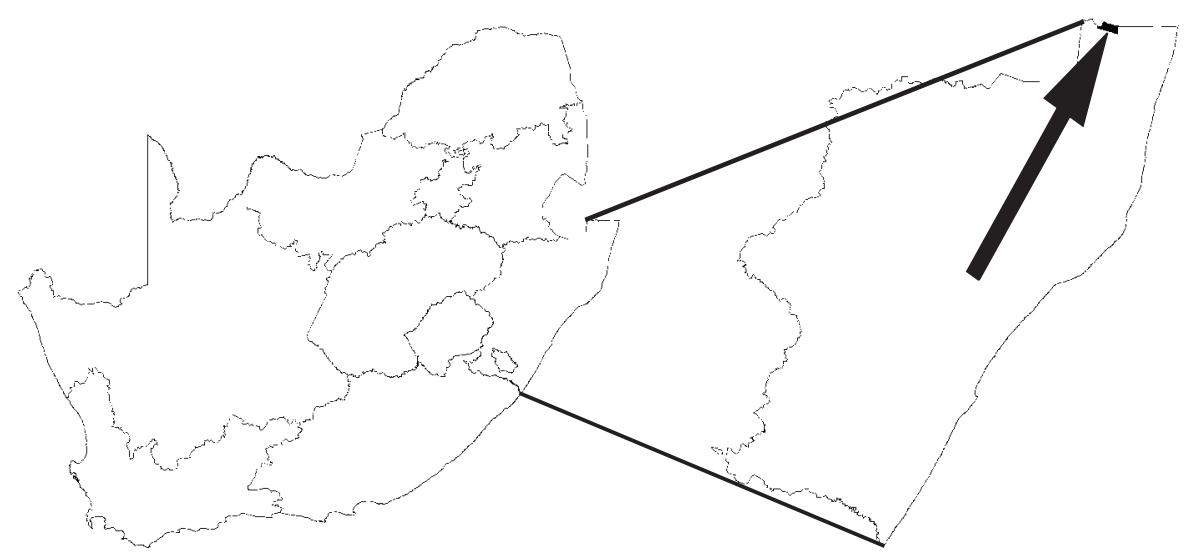

Fig. 1. Location of the Ndumo Game Reserve in northern KwaZulu-Natal, South Africa, as indicated by the arrow

of spiders in the Tembe Elephant Park and surrounding areas. Consequently, large gaps exist in the knowledge of spider diversity of Maputaland. The question raised is whether, for this group of invertebrates, Maputaland represents a centre of endemism, as is the case for other biological taxa such as plants (Matthews et al. 2001; Van Wyk \& Smith 2001).

Although there are a limited number of published papers dealing specifically with spider diversity in the undisturbed conservation areas of South Africa, surveys have steadily increased during the last decade, largely due to the initiation of the South African National Survey of Arachnida (SANSA). This initiative aims, in part, to provide biodiversity information on arachnids in South Africa's conservancies, identify biodiversity hotspots, and aid conservation planning. As a consequence, several papers have now been published (Dippenaar-Schoeman 1988, 2006; Dippenaar-Schoeman \& GonzalezReyes 2006; Dippenaar-Schoeman \& Leroy 2003; Dippenaar-Schoeman et al. 1989, 1999, 2005; Foord et al. 2002; Whitmore et al. 2001).

The relatively poor knowledge of the arachnids of Maputaland provided the impetus to set up a checklist for Ndumo Game Reserve. Although specimens of all of the arachnid orders (excluding Acari) were collected, the primary focus of this study was on the spiders (Araneae), which was done with the aim of providing a baseline for future ecological research. This study forms part of the SANSA projects in conservancies and the Savanna Biome.

\section{Study area}

The Ndumo Game Reserve (NGR) is situated in Maputaland, a geographical bioregion covering the northern-most parts of the KwaZulu-Natal Province, South Africa, and the southern parts of Mozambique (Fig. 1). The game reserve borders on Mozambique to the north (Usutu [Usuthu] River), and lies close to South Africa's border with Swaziland to the west. The NGR covers an area of 10117 ha, and falls within the BushveldSavanna ecozone of southern Africa (Grant \& Thomas 1998).

A rich habitat variety can be found at NGR (De Moor et al. 1977), but for the purposes of this study they are grouped into eight broad habitat types, which are briefly described here. Classification of plants follows Germishuizen et al. (2006):

1. Acacia tortilis (Forssk.) Hayne (umbrella thorn) savanna (AS)-situated in the south-western parts of the reserve. This 
habitat type is dominated by $A$. tortilis, Albizia anthelmintica (A.Rich.) Brongn. and A. petersiana (Bolle) Oliv. trees, and has a well-developed grass layer (Figs 2-3), including Aristida adscensionis L., Chloris pycnothrix Trin., C. virgata Sw., Enteropogon macrostachyus (Vahl) K.Schum., Hyperthelia dissoluta (Nees ex Steud.) Clayton, Setaria sp., Sporobolus fimbriatus (Trin.) Nees and Themeda triandra Forssk.

2. Deciduous broadleaf woodland (BW) - situated in the southern, higher lying parts of the reserve. This is a highly diversified savanna habitat, with extreme variations in plant composition and vegetative density (Fig. 4). Common trees include Acacia burkei Benth., Albizia adianthifolia (Schumach.) W.Wight, $A$. petersiana, Combretum molle R.Br. ex G.Don, Dichrostachys cinerea (L.) Wight \& Arn., Grewia occidentalis L., Sclerocarya birrea (A.Rich.) Hochst., Strychnos madagascariensis Poir., Terminalia sericea Burch. ex DC., Trichilia emetica Vahl and Ziziphus mucronata Willd. Various short shrubs, including Chionanthus peglerae (C.H.Wright) Stearn, Maytenus sp., Olinia sp. and Teclea natalensis (Sond.) Engl., dominate the lower strata of the habitat. Common grasses include Aristida adscensionis, Cymbopogon nardus (L.) Rendle, Cynodon dactylon, Dactyloctenium spp., Digitaria eriantha Steud., various Eragrostis spp. (E. lehmanniana Nees, E. rigidior Pilg. and E. superba Peyr.), Heteropogon contortus (L.) Roem. \& Schult., Hyperthelia dissoluta (Nees ex Steud.) Clayton, Panicum maximum Jacq., $P$. repens L. and Setaria species.

3. Sand forest (SF)-situated in the south east of the reserve. Sand forest is more typical of the Tembe Elephant Park (Matthews et al. 2001) and is a habitat unique to Maputaland. Only a small patch is found in Ndumo at the bottom of Ndumo hill along the southern boundary fence. Common trees and shrubs include Artabotrys monteiroae Oliv., Carissa bispinosa (L.) Desf. ex Brenan, Commiophora neglecta I.Verd., Haplocoelum foliosum (Hiern) Bullock, Hymenocardia ulmoides Oliv., Phyllanthus sp. and Spirostachys africana Sond. The ground is generally devoid of any grass, and short plants (Asparagus africanus Lam., A. falcatus L. and Sansevieria hyacinthoides (L.) Druce, amongst others) occur sporadically in the habitat (Fig. 5).

4. Subtropical bush (ST), which covers the largest area of the reserve, is a heterogeneous habitat composed largely of Mahemene thicket and Acacia nigrescens Oliv. woodland (De Moor et al. 1977). Although other habitat types can be included under subtropical bush, sampling was primarily carried out in these two habitats. Dominant trees include various Acacia spp. (including A. burkei, A. karroo Hayne and A. nigrescens), Albizia species (including $A$. anthelmintica, A. petersiana and $A$. versicolor Welw. ex Oliv.), Apodytes dimidiata E.Mey. ex Arn., Balanites maughamii Sprague, Euclea species (E. crispa (Thunb.) Gürke, $E$. daphnoides Hiern and E. divinorum Hiern), Euphorbia ingens E.Mey. ex Boiss., Ptaeroxylon obliquum (Thunb.) Radlk., Trema orientalis (L.) Blume and Vepris lanceolata (Lam.) G.Don. Shrubs and shorter plants include Carissa bispinosa, Croton menyharthii Pax, Euphorbia grandicornis Goebel ex N.E.Br., Hypericum sp., Gardenia spp., Grewia bicolor Juss., Sansevieria hyacinthoides and Tarchonanthus camphoratus L. The grass and herb layer is highly variable, in some areas consisting primarily of the creepers Cissus rotundifolia (Forssk.) Vahl and Crassula sp. (Acacia nigrescens woodland), while other areas, including Mahemane thicket, consist primarily of short grasses such as Chloris spp., Dactyloctenium spp., Eragrostis spp. and Setaria verticillata (L.) P.Beauv., with Cissus rotundifolia creepers found near the base of trees (Figs 6-7).

5. Acacia xanthophloea Benth. (fever tree) forests (AX)-situated around the margins of the freshwater pans Banzi, Hotwe, Nyamiti [Nyamithi] and Shokwe, in rela- 

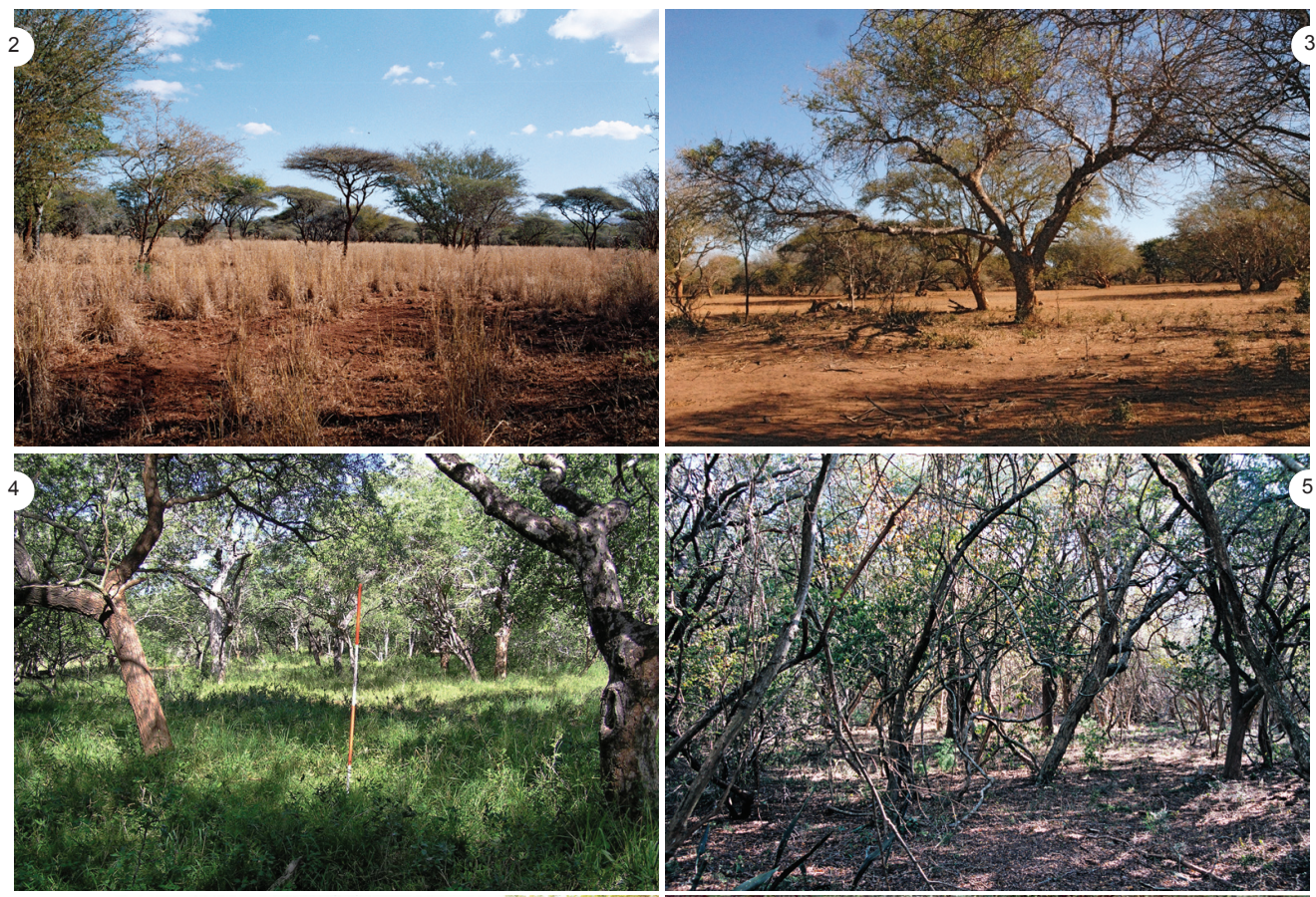

6
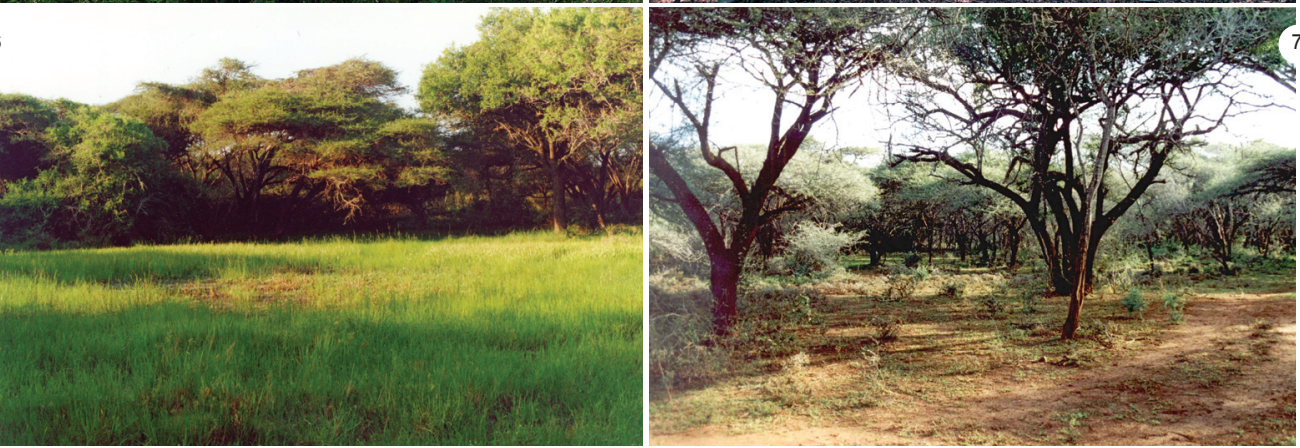

Figs. 2-7. Savanna and associated habitats in Ndumo Game Reserve: 2-3) Acacia tortilis savanna (AS) dominated by Acacia tortilis (2) and Albizia spp. (3) trees; 4) Deciduous broadleaf woodland (BW); 5) Sand forest (SF); 6-7) Subtropical bush (SB) consisting of Mahemane thicket (6) and Acacia nigrescens woodland (7).

tively localised areas. This habitat type is strongly dominated by Acacia xanthophloea trees, with shorter shrubs (e.g. Carissa and Grewia spp.). Weeds such as Solanum spp. occur sporadically (Figs 8-9). Cynodon dactylon (L.) Pers. is the dominant grass species, although the taller Cyperus sp. and Leptochloa fusca (L.) Kunth are also present in places. In some areas (e.g. some sites at Banzi Pan) grasses were entirely absent.
6. Floodplain (FP)—situated inland from riparian forests along the Pongola [Phongolo] and Usutu Rivers. This habitat is dominated by the reed species Phragmites australis (Cav.) Steud. and $P$. mauritianus Kunth, and various shorter grasses and sedges, including Cynodon dactylon, Cyperus fastigiatus Rottb. and Echinochloa pyramidalis (Lam.) Hitchc. \& Chase (Figs 10-11). Trees and shrubs occur sporadically along the floodplain, 

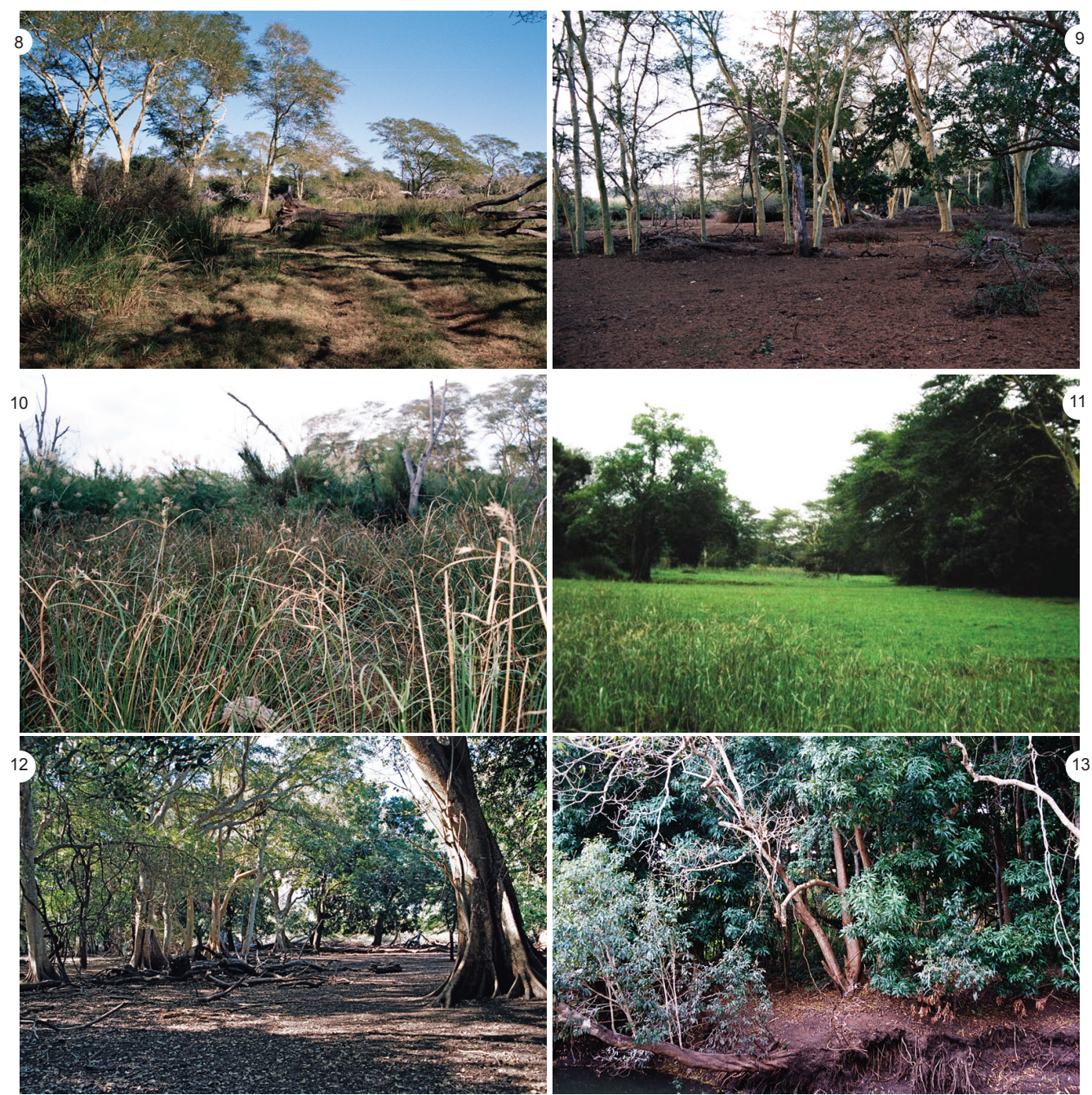

Figs. 8-13. Floodplain and associated habitats in Ndumo Game Reserve: 8-9) Fever tree or Acacia xanthophloea forests at Shokwe pan (8) and Banzi pan (9). Note the differences in understory plant growth; 10-11) Floodplain vegetation (FP); 12) Wild fig or Ficus forest (FF) at Shokwe pan; 13) Riparian forest (RF) at the Pongola River.

and include Acacia xanthophloea, Ficus sycomorus L., Grewia caffra Meisn., Gymnosporia senegalensis (Lam.) Loes. and Kigelia africana (Lam.) Benth., and are often covered near their trunks by Monanthotaxis caffra (Sond.) Verdc. creepers.

7. Ficus (wild fig tree) forests (FF) - situated around the margins of the freshwater pans Shokwe and Banzi, and along rivers. This habitat is dominated by wild fig trees (particularly $F$. sycomorus and $F$. sur Forssk.), and is characterised by a near absence of shrubs and grasses, and presence of a very well developed leaf litter layer (Fig. 12). Other trees that occur sporadically in the habitat include $A$. xanthophloea, Breonadia salicina (Vahl) Hepper \& J.R.I.Wood, K. africana and Trichilia emetica.

8. Riparian forest (RF) — situated along the banks of the Usutu and Pongola rivers 
(Fig. 13). This habitat is dominated by tall trees including B. salicina, F. sur, F. sycomorus, Harpephyllum caffrum Bernh., Olea capensis L. and Rauvolfia caffra Sond., with $M$. caffra creepers frequently growing between trees. Shrubs present include Antidesma venosum E.Mey. ex Tul., Grewia caffra, Tarenna pavettoides (Harv.) Sim. and Tricalysia species. A dense leaf litter layer is present, and grasses (e.g. Cynodon dactylon, Hemarthria altissima (Poir.) Stapf \& C.E.Hubb. and Ischaemum spp.) only occur very sporadically.

Sampling was generally limited to winter, when game counts (wildlife censuses) were conducted, and mid-summer. Arachnids were collected during the following periods: July 2000 (2 weeks); November-December 2000 (4 weeks); January (1 week) and July 2002 (2 weeks); June-July 2003 (2 weeks); July 2004 (2 weeks); February (1 week) and June 2005 (2 weeks), and January 2006 (2 weeks), April (1 week) and June 2006 (2 weeks).

\section{Methods}

Sampling was conducted primarily on an ad hoc basis, and was not quantitative. Consequently, sampling intensity in each habitat varied considerably. For example, sand forest was relatively poorly sampled, while deciduous broadleaf woodland and subtropical bush were very well sampled.

The sampling methods for each arachnid guild can be summarised as follows: ground wanderers were sampled using pitfall traps, rock and log turning, and leaf litter sifting; plant wanderers were collected using beating sheets and by hand (trees), and sweep-nets and by hand (grass); web-builders were collected by hand and sweep-nets; spiders were collected on or under bark with a pooter, using a modified net, or by hand. Night collecting was done by hand with the aid of a flashlight. Spiders attracted to light traps at night were also collected. Specimens were preserved in $70 \%$ ethanol for each site sampled.

The second author identified most of the material to species level, while the third author identified the Salticidae. Various taxa were identified by the specialists listed in the Acknowledgments. Voucher specimens have been deposited in the following institutions: Royal Museum of Central Africa, Tervuren, Belgium (Linyphiidae, Salticidae and Zodariidae); National Museum, Bloemfontein, South Africa (Miturgidae, Sicariidae and Opiliones); Western Australian Museum, Perth, Australia (Pseudoscorpiones); Zoological Institute and Museum Alexander Koenig, Bonn, Germany (Pholcidae); American Museum of Natural History, New York, U.S.A. (Scorpiones); and the National Collection of Arachnida, ARC-Plant Protection Research Institute, Pretoria, South Africa (all other arachnids).

\section{Guilds observed}

Two main guilds can be distinguished among arachnids, namely wanderers and web-builders. The wanderers can be further divided into plant wanderers (PW) and ground wanderers (GW). Plant wanderers were separated and placed in a guild based on the vegetation type that they were most commonly found on, namely plant wanderer on foliage (PWF), plant wanderer on grass $(\mathrm{PWG})$ and plant wanderer on bark (PWB).

The web-building spiders can also be subdivided into different guilds based on the structure of the webs that they build: sheet-web builders (SWB), spaceweb builders (SPWB), orb-web builders (OWB), modified orb-web builders (MOWB), funnel-web builders (FWB), retreat-web builders (RWB) and gum-foot-web builders (GWB).

Table 1

Order composition of the non-acarine arachnids in the Ndumo Game Reserve, Maputaland

\begin{tabular}{llccc}
\hline Order & \multicolumn{1}{c}{ Common Name } & Families & Genera & Species \\
\hline Amblypygi & Tailless whip-scorpions & 1 & 1 & 1 \\
Araneae & Spiders & 46 & 222 & 431 \\
Opiliones & Harvestmen & 2 & 2 & 3 \\
Pseudoscorpiones & False scorpions & 6 & 8 & 12 \\
Scorpiones & Scorpions & 3 & 5 & 8 \\
Solifugae & Sun spiders & 1 & 2 & 2 \\
\hline Total & & 59 & 240 & $\mathbf{4 5 7}$ \\
\hline
\end{tabular}


Table 2

Proportional diversity of the non-acarine arachnid orders in Ndumo Game Reserve relative to total South African (Dippenaar-Schoeman \& Haddad, unpubl.) and global (Harvey 2002) diversity of each order

\begin{tabular}{lcccccc}
\hline Order & \multicolumn{2}{c}{ NGR } & \multicolumn{2}{c}{ South Africa } & \multicolumn{2}{c}{ Global } \\
\hline & Species & $\%$ & Species & $\%$ & Species & $\%$ \\
\hline Araneae & 431 & 94.52 & 2000 & 78.03 & 36000 & 74.70 \\
Pseudoscorpiones & 12 & 2.63 & 135 & 5.27 & 3239 & 6.72 \\
Scorpiones & 8 & 1.75 & 93 & 3.63 & 1279 & 2.65 \\
Opiliones & 3 & 0.66 & 179 & 6.98 & 6000 & 12.45 \\
Solifugae & 2 & 0.44 & 150 & 5.85 & 1087 & 2.26 \\
Amblypygi & 1 & 0.22 & 3 & 0.12 & 136 & 0.28 \\
Others & 0 & 0.00 & 3 & 0.12 & 451 & 0.94 \\
\hline & 457 & $\sim 100.00$ & 2563 & $\sim 100.00$ & 48192 & $\sim 100.00$ \\
\hline
\end{tabular}

Specimens were identified in the laboratory and placed within a particular guild. Additional notes were made of the habitats in which each species was collected, and information on the habits of some species was gathered to provide a fuller picture of the ecology of the spiders within the reserve.

\section{Results and Discussion}

\section{Diversity}

In total, 457 species representing six orders, 59 families and 240 determined genera of arachnids were collected (Appendix 1, Table 1). The greatest diversity was found in the Araneae (46 families, 431 spp.), followed by the Pseudoscorpiones ( 6 families, 12 spp.), Scorpiones (3 families, 8 spp.), Opiliones ( 2 families, 3 spp.) and Solifugae (1 family, 2 spp.). The Amblypygi was only represented by a single species. Compared to the high diversity of spiders collected, the other arachnid orders (excluding Acari) are under-represented relative to the global arachnid diversity of each order (Table 2; Harvey 2002; Dippenaar-Schoeman \& Haddad unpubl.). The under-representation of some of these orders (Solifugae and Scorpiones) could be attributed to their generally higher diversity in more arid environments, and lower diversity in subtropical environments, in southern Africa (Lawrence 1955, 1963; Prendini 2005).

The most diverse families collected were the Salticidae (82 spp.), followed by the Thomisidae (51 spp.) and Araneidae (38 spp.). Eighteen families were represented by a single species only. The total spider diversity (431 spp.) represents the highest number of species recorded from a single conservancy surveyed in South Africa thus far. Previous surveys have yielded between 75 and 268 species (Table 3). It must be noted that the current study took place over

Table 3

Currently known total species diversity of spiders (Araneae) recorded from South African conservancies

\begin{tabular}{lccl}
\hline Conservancy & Families & Species & Reference \\
\hline Karoo National Park & 38 & 116 & Dippenaar-Schoeman et al. (1999) \\
Kruger National Park & 40 & 152 & Dippenaar-Schoeman \& Leroy (2003) \\
Makalali Game Reserve & 38 & 268 & Whitmore et al. (2001) \\
Mountain Zebra National Park & 34 & 75 & Dippenaar-Schoeman $(1988,2006)$ \\
Ndumo Game Reserve & 46 & 431 & Present study \\
Roodeplaat Dam Nature Reserve & 27 & 110 & Dippenaar-Schoeman et al. (1989) \\
Soutpansberg West Conservancy & 46 & 127 & Foord et al. (2002) \\
Swartberg Nature Reserve & 45 & 186 & Dippenaar-Schoeman et al. (2005) \\
\hline
\end{tabular}




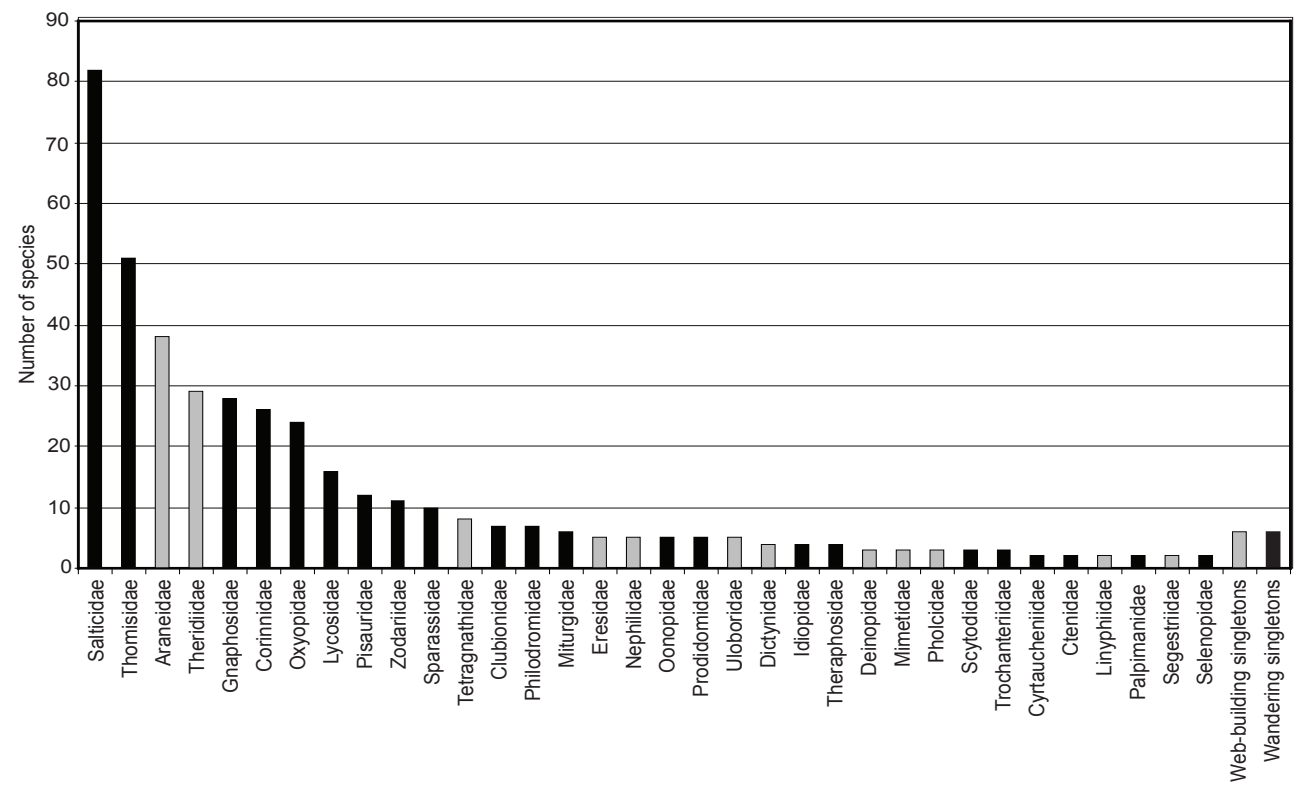

Fig. 14. Species diversity of spider families collected in Ndumo Game Reserve ranked from highest to lowest. Black bars indicate wandering spiders and grey bars indicate web-builders.

a period of seven years (11 intensive sampling trips). Furthermore, a wide variety of sampling methods were used in most strata of the habitats present, while many of the other surveys were restrictive in terms of sampling intensity (often ad hoc sampling) or methods. The survey in Roodeplaat Dam Nature Reserve only involved the field and tree layer and did not include ground-dwelling arachnids (Dippenaar-Schoeman et al. 1989).

\section{Guilds}

The vast majority of the arachnids collected were wanderers $(75.9 \%)$, with web-builders comprising $24.1 \%$ of the species. Amongst spiders only, wanderers contributed a much higher proportion of the species (Fig. 14), with two families (Salticidae and Thomisidae) contributing more than $32 \%$ of the total spider species. Two of the diverse webbuilding families, Araneidae and Theridiidae, contributed $15.5 \%$ of the spider species, combined.

\section{Common taxa by stratum}

Since this study was not conducted quantitatively there is no specific data available on the abundance of particular species in each habitat. However, based on observations and collecting frequency during this study the following patterns emerged for each stratum and guild:

Ground wanderers: A large number of species (Appendix 1) are wandering arachnids on the ground surface. The community composition varied greatly between different habitats. Open savanna habitats (AS, BW) were dominated by various gnaphosid genera (Asemesthes, Zelotes, Setaphis and Camillina), lycosids (Geolycosa sp. and Evippomma squamulatum (Simon)), corinnids (Merenius alberti Lessert, Copa flavoplumosa Simon and Castianeira sp.), salticids (Mexcala elegans Peckham \& Peckham, Stenaelurillus and Phlegra spp.) and zodariids (Caesetius bevisi (Hewitt), Capheris sp., Palfuria sp. and Psammorygma sp.), while Uroplectes olivaceus Pocock (Buthidae), Opistacan- 
thus spp. (Liochelidae), Brachionopus sp. (Theraphosidae), Scytodes caffra Lawrence (Scytodidae), Loxoscelis spinulosa Purcell (Sicariidae) and Caponia chelifera Lessert (Caponiidae) were most common under logs and rocks.

The fauna of floodplain habitats (AX, FF, FP) was strongly dominated by wolf spiders (Lycosidae), gnaphosids (particularly Zelotes spp.), corinnids (particularly M. alberti) and salticids (Thyenula spp. and Evarcha spp.). Metabiantes maximus Lawrence (Biantidae) and Scytodes spp. (Scytodidae) were common under logs in these habitats.

The remaining two forest types studied differed considerably in their faunas. Riparian forest was dominated by Zelotes spp., Merenius alberti, Copa flavoplumosa, Thyenula spp., and various lycosids and oonopids. Spider densities also appear to be much higher than in sand forest. The latter habitat was dominated by lycosid spiders, with oonopids and corinnids in lower densities.

Subtropical bush had relatively similar faunas. Mahemane thicket areas were dominated by salticids (Stenaelurillus spp. and Phlegra spp., and Mexcala elegans), lycosids, oonopids and gnaphosids of the genera Asemesthes, Camillina, Setaphis and Zelotes, while Acacia nigrescens woodland areas were dominated by lycosids, salticids and liochelid scorpions.

Ground web-builders: Web-builders near the ground surface were generally uncommon, and were largely limited to amaurobiids, Euprosthenops vuattouxi Blandin (Pisauridae), Xeviosa amica Griswold (Phyxelididae), Ariadna spp. (Segestriidae) and Hippasa australis Lawrence (Lycosidae), which were found in contrasting habitats (Appendix 1). The latter species was the only species that was widespread in NGR, occurring in all of the habitats sampled. Linyphiid and hahniid sheet-web builders were most common in ST leaf litter.

Wanderers associated with bark: Due to the variable plant composition of the different habitats, arachnids associated with bark varied considerably. The habitat best sampled was AX, with a survey having been conducted specifically on the arachnids associated with Acacia xanthophloea bark at five pan and floodplain sites in the reserve (Haddad unpubl.). The most common associations with this tree species are Cetonana spp. (Corinnidae), Pseudicius spp. and Heliophanus spp. (Salticidae), various gnaphosids, miturgids (Cheiracanthium spp. and Cheiramiona spp.), Hersilia sericea Pocock (Hersiliidae), Platyoides spp. (Trochanteriidae) and Clubiona spp. (Clubionidae). In the Ficus forest (FF) and floodplain (FP) a similar fauna was found, but densities were generally lower, probably due to the more variable bark structure. Pseudoscorpions, particularly atemnids (e.g. Titanatemnus natalensis Beier), and buthid scorpions (particularly Uroplectes spp. and Pseudolycus pegleri (Purcell)) were also very common under the bark of trees in these habitats.

The arachnids associated with tree bark in RF and SF differed considerably. In RF, the fauna contained elements of Ficus forest, which can be explained by the presence of Ficus spp. in this habitat. In SF, jumping spiders (particularly Holcolaetis zuluensis Lawrence and Pseudicius spp.) were most common, with lesser numbers of Hersilia sericea and Clubiona spp. present.

Trees in AS, BW and ST generally had a coarser bark structure compared to the aforementioned habitats. Wandering spiders were largely limited to $H$. sericea, Clubiona spp., Philodromus spp. (Philodromidae) and various salticids.

Web-builders associated with bark: As for wanderers, AX also had a high diversity and abundance of web-builders compared to other habitats. The most widespread and common species associated with bark in the eight habitats include various theridiids (Theridion spp., Euryopis sp. and Argyrodes spp.), araneids (particularly Neoscona spp.), and on occasion Nephilengys cruentata (Fabricius) (Nephilidae).

Wanderers on grass: Grasses were particularly widespread in $\mathrm{AS}$ and $\mathrm{BW}$, where a large proportion of sampling was undertak- 
en. Common wanderers in these two habitats include various salticids (particularly Thyene, Viciria and Heliophanus spp.), Philodromus and Tibellus spp. (Philodromidae), Oxyopes spp. (Oxyopidae) and Thomisus, Runcinia and Synema spp. (Thomisidae).

In the two floodplain habitats (AX and FP) the grass fauna was dominated by immature lycosids, Heliophanus spp., Oxyopes spp., Charminus spp. and Afropisaura rothiformis (Simon) (Pisauridae), and Thomisus species. The grass fauna of ST was dominated by Charminus and Oxyopes spp., with other common taxa including Synema, Thomisus, Thyene and Hyllus species. Grasses were largely or entirely absent from FS, RF and $\mathrm{SF}$, and consequently little data could be generated for these habitats.

Web-builders in grass: The AS and BW grasslands were a rich source of web-building spiders, particularly for the families Araneidae (Neoscona, Hypsosinga, Isoxya and Singa spp.), Dictynidae (Archaeodictyna and Dictyna spp.) and Theridiidae (Latrodectus geometricus C. L. Koch and Theridion spp.). Most of these species construct a retreat or web in the florescences of various grasses.

In the floodplain habitats AX and FP, webbuilders primarily included various Tetragnatha spp. (Tetragnathidae), Neoscona, Argiope and Araniella spp. (Araneidae) and small theridiids. Web-builders in ST grasses were generally uncommon due to the short grasses present, and consisted mainly of immature araneids and theridiids.

Wanderers on foliage: All of the habitats have a well-developed tree layer and there was generally a large degree of overlap in the faunas between habitats. Generally, the most common wandering spiders throughout NGR include many of the Thomisidae (particularly Thomisus, Monaeses, Thomisops and Synema spp., and Misumenops rubrodecoratus Millot), Salticidae (especially Hyllus, Evarcha, Heliophanus, Thyene and Pseudicius spp.), Oxyopidae (Oxyopes and Hamataliwa spp.), Clubiona spp. and Miturgidae (especially Cheiramiona spp.). In particular, Philodromidae were very common on thorn trees in AS, while being less frequently encountered in the other habitats.

Web-builders on foliage: The web-building arachnids showed greater habitat variation than the wanderers, which could be related to spacing between trees and shrubs in which webs can be constructed. The savanna and woodland habitats (AS, BW and ST) had higher densities of large and colourful araneids (Gasteracantha milvoides Butler, Cyrtophora citricola (Forskål), Caerostris and Isoxya spp.) and the nephilid Nephila senegalensis (Walckenaer) than the other habitats in the reserve. In contrast, riverine and floodplain habitats had high densities of $G$. milvoides, $N$. fenestrata Thorell and $N$. inaurata (Walckenaer). The SF fauna comprised largely of small araneid spiders, particularly Araniella and Neoscona. Theridiid, dictynid and araneid spiders were common on small shrubs and trees at AX, FF, FP and RF, while araneid, theridiid and uloborid spiders were common in AS, BW and ST.

\section{Conservation implications}

The high species diversity of arachnids, and spiders in particular, as a single taxon group suggests that other invertebrate taxa may similarly display high levels of diversity in Ndumo Game Reserve. Approximately $18 \%$ and $22 \%$ of the total South African non-acarine arachnid, and spider diversity, respectively (Table 2), is currently conserved in this reserve. Thus, further study on the invertebrates is needed to discover the extent of the richness of the Maputaland fauna. The high diversity of a single taxon should serve as strong supportive evidence of the need to create awareness of the plight of invertebrate conservation, and increase the area under conservation in this part of South Africa.

Species of notable conservation importance include the four baboon spiders (Theraphosidae) collected. Ceratogyrus bechuanicus Purcell is already considered to be a threatened species due to the pet trade (De Wet \& Dippenaar-Schoeman 1991). The Brachionopus $\mathrm{sp}$. is unlikely to be seriously threatened, and was encountered very frequently under logs 
and rocks throughout the reserve. The new species of Idiothele is of particular conservation importance. This species has unique blue setae on the metatarsi and tarsi, a trait that could make them especially susceptible to collectors for the pet trade. This species is presently only known from Ndumo, and thus any restrictions possible to limit collection of this species should be imposed.

Numerous new species were discovered in this study, emphasising the need to continue work on all invertebrate taxa so that the knowledge base of South Africa's fauna can be increased. The study also provided new information on the distribution of all species concerned, including several species recorded from South Africa for the first time, and provided material that can be used for taxonomic studies. This highlights the important contribution that the SANSA initiative makes to a better knowledge of the diversity of arachnids in South Africa.

\section{Acknowledgments}

KZN Wildlife is thanked for their interest in and support for this project, particularly Catharine Hanekom, Wayne Matthews, Adrian Armstrong, Peter Ruinard and Jabulani Ngubane, and for providing collecting permits for this study (Sharron Hughes). The following taxonomists are thanked for providing identifications of specimens: Leon Lotz (National Museum, Bloemfontein-Miturgidae, Sicariidae and Opiliones), Rudy Jocqué (Royal Museum for Central Africa, Tervuren-Linyphiidae and Zodariidae), Mark Harvey (Western Australian Museum, Perth - Pseudoscorpiones), Bernhard Huber (Zoological Institute and Museum Alexander Koenig, Bonn - Pholcidae) and Mark Alderweireldt and Tony Russell-Smith (Lycosidae). Johan Venter, Andor Venter and Samantha Oliver (University of the Free State, Bloemfontein) and Wayne Matthews provided assistance with the identification of plant specimens. Catharine Hanekom, Wayne Matthews and Adrian Armstrong are thanked for their comments on the manuscript. John Clarke and Catharine Hanekom provided the photos of the Acacia tortilis savanna and deciduous broadleaf woodland, respectively. The Faculty of Natural and Agricultural Sciences and Department of Zoology and Entomology of the University of the Free State gave financial and logistical support during the early parts of the survey. Many students from the University of the Free State provided assistance with fieldwork during the course of the study. Particular mention should be given to Vaughn Swart, Johann van As, Jonathan Venter, Ilse Els, Stefan van As, John Clarke and Frikkie Spangenberg, who assisted with the initial surveys.

\section{References}

De Moor, P.P., E. Pooley, G. Neville \& J. BarICHIEVY. 1977. The vegetation of Ndumo Game Reserve, Natal: A quantitative physiognomic survey. Annals of the Natal Museum 23: 239272.

De Wet, J.I. \& A.S. DippenaAr-Schoeman. 1991. The occurrence and conservation status of Ceratogyrus bechuanicus and C. brachycephalus in the Transvaal, South Africa. Koedoe 34: 69-75.

DipPEnAAR-SchoEMAN, A.S. 1988. Annotated check list of the spiders (Araneae) of the Mountain Zebra National Park. Koedoe 31: 151-160.

DippenaAR-Schoeman, A.S. 2006. New records of 43 spider species from the Mountain Zebra National Park, South Africa (Arachnida: Araneae). Koedoe 49(2): 23-28.

Dippenaar-Schoeman, A.S. \& A.X. GonzalezREYES. 2006. South African National Survey of Arachnida (SANSA): Solifugae (sun-spiders) of the National Parks and reserves of South Africa (Arachnida, Solifugae). Koedoe 49(2): 29-38.

DippenaAr-Schoeman, A.S. \& A. Leroy. 2003. A check list of the spiders of the Kruger National Park, South Africa (Arachnida: Araneae). Koedoe 46: 91-100.

DippenaAr-Schoeman, A.S., A. Leroy, M. de Jager \& A. VAN DEN BERG. 1999. A check list of the spider fauna of the Karoo National Park, South Africa (Arachnida: Araneae). Koedoe 42: 31-42.

DippenaAr-Schoeman, A.S., A.M. van den Berg \& A. VAN DEN BERG. 1989. Species composition and relative seasonal abundance of spiders from the field and tree layers of the Roodeplaat Dam Nature Reserve. Koedoe 32: 25-38.

DippenaAr-Schoeman, A.S., A.E. VAN Der Walt, M. DE JAger, E. LE Roux \& A. VAN DEN BerG. 2005. The spiders of the Swartberg Nature Reserve in South Africa (Arachnida: Araneae). Koedoe 48: 77-86.

DippenaAr-Schoeman, A.S. \& T.D. WassenaAR. 2002. A checklist of the ground-dwelling spiders of coastal dune forests at Richards Bay, South Africa (Arachnida: Araneae). Bulletin of the British Arachnological Society 12: 275-279.

DippenaAr-Schoeman, A.S. \& T.D. WassenaAr. (in press). A checklist of spiders from the herbaceous layer of a coastal dune forest ecosystem at Richards Bay, KwaZulu-Natal, South Africa (Arachnida: Araneae). African Invertebrates. 
DixON, J.E.W. 1966. Notes on the mammals of Ndumu Game Reserve. The Lammergeyer 6: 24-40

Foord, S.H., A.S. DippenaAR-SchOeman \& M. VAN DER MERWE. 2002. A check list of the spider fauna of the Western Soutpansberg, South Africa (Arachnida: Araneae). Koedoe 45: 35-43.

Germishuizen, G., N.L. Meyer, Y. Steenkamp \& M. KEITH. 2006. A checklist of South African plants. Pretoria: SABONET. (South African Botanical Diversity Network; report no. 41.)

Grant, R. \& V. Thomas. 1998. Sappi tree spotting: KwaZulu/Natal coast \& midlands. Johannesburg: Jacana.

HADDAD, C.R. 2003. The fruit chafers (Coleoptera: Scarabaeidae: Cetoniini) of the Ndumo Game Reserve and Tembe Elephant Park, KwaZuluNatal. African Entomology 11: 130-133.

HADDAD, C.R. (in press). A new species of Corinnomma (Araneae: Corinnidae) from southern and eastern Africa, with taxonomic notes on $C$. olivaceum and C. semiglabrum. African Invertebrates.

HARVEY, M.S. 2002. The neglected cousins: what do we know about the smaller arachnid orders? Journal of Arachnology 30: 357-372.

LAWRENCE, R.F. 1937a. New harvest spiders from Natal and Zululand. Annals of the Natal Museum 8: 127-153.

LAWRENCE, R.F. 1937b. A collection of Arachnida from Zululand. Annals of the Natal Museum 8: 211-273.

LAWRENCE, R.F. 1938. A collection of spiders from Natal and Zululand. Annals of the Natal Museum 8: 455-524.

LAWRENCE, R.F. 1942a. A contribution to the araneid fauna of Natal and Zululand. Annals of the Natal Museum 10: 141-190.

LAWRENCE, R.F. 1942b. The scorpions of Natal and Zululand. Annals of the Natal Museum 10: 221-235.

LAWRENCE, R.F. 1952. New spiders of the eastern half of South Africa. Annals of the Natal Museum 12: 183-226.

LAWrENCE, R.F. 1955. Solifugae, Scorpions, and Pedipalpi, with checklists and keys to the South African families, genera, and species. South African Animal Life 1: 152-262.
LAWrence, R.F. 1963. The Solifugae of South West Africa. Cimbebasia 8: 1-28.

Lawrence, R.F., P.M.C. Croeser \& A.S. DippenaARSCHOEMAN. 1980. 15. Spiders of Maputaland with notes on associated Arthropods. Pp. 146-163. In: Bruton, M.N. \& K.H. Cooper (eds.). Studies of the ecology of Maputaland. Durban: Rhodes University and the Natal Branch of the Wildlife Society of Southern Africa.

Lyle, R. \& C.R. HAdDAD. (in press). A revision of the Afrotropical tracheline sac spider genus Thysanina Simon, 1910 (Araneae: Corinnidae). African Invertebrates.

Matthews, W.S., A.E. Van Wyk, N. Van Rooyen \& G.A. BothA. 2001. Vegetation of the Tembe Elephant Park, Maputaland, South Africa. South African Journal of Botany 67: 573-594.

Pooley, A.C. 1965. A preliminary check list of the reptiles within the Mkuzi and Ndumu Game Reserves in Northern Zululand. The Lammergeyer 3: 41-55.

Prendini, L. 2005. Scorpion diversity and distribution in southern Africa: Pattern and process. Pp. 25-68. In: Huber, B.A., B.J. Sinclair \& K.-H. LAMPE (eds.). African Biodiversity: Molecules, Organisms, Ecosystems. Proceedings of the 5th International Symposium on Tropical Biology, Museum Alexander Koenig, Bonn. New York: Springer Verlag.

RAMSAR 2001. The Annotated Ramsar List of Wetlands of International Importance: South Africa. Available at http://www.ramsar.org/profile/profiles_southafrica.htm Retrieved: 14/07/2006.

VAn der Merwe, M., A.S. DippenaAr-Schoeman \& C.H. ScholTz. 1996. Diversity of ground-living spiders at Ngome State Forest, KwaZulu-Natal: a comparative survey in indigenous forest and pine plantations. African Journal of Ecology 34: 342-350.

VAn WyK, A.E. \& G.F. Smith. 2001. Regions of floristic endemism in Southern Africa: A review with emphasis on succulents. Hatfield: Umdaus.

Whitmore, C., R. Slotow, T.E. Crouch \& A.S. DipPENAAR-SCHOEMAN. 2001. Checklist of spiders (Araneae) from savanna ecosystem, Northern Province, South Africa: including a new family record. Durban Museum Novitates 26: 10-19. 
Appendix 1

A checklist of the arachnids of the Ndumo Game Reserve.

Guild abbreviations are provided in the text. Habitat abbreviations: $A S$ - Acacia tortilis savanna; $A X-$ Acacia xanthophloea forests around pans; $B W$ - Broadleaf woodland; FF - Ficus forest; FP - Floodplain vegetation near the Pongola and Usutu rivers; $R F$ - riparian forests along Pongola and Usutu rivers; SF - Sand forest; ST-Subtropical bush. Symbols: $\propto$ indicates a new genus and species, $\dagger$ indicates a new species, $\neq$ a possible new species, and? an uncertain determination

\begin{tabular}{lll}
\hline Family/Genus/Species & Guilds & Habitats \\
\hline
\end{tabular}

ORDER: AMBLYPYGI (tailless whip-scorpions)

FAMILY: PHYRNICHIDAE

Damon variegatus (Perty, 1834)
GW

BW, FP, RF, SF, ST

ORDER: ARANEAE (spiders)

FAMILY: AGELENIDAE

Agelena sp.

FAMILY: AMAUROBIIDAE

Macrobuninae sp.

FAMILY: AMMOXENIDAE

Rastellus florisbad Platnick \& Griffin, 1990

FAMILY: ARANEIDAE

Afroxya camerunensis (Thorell, 1899)

Arachnura scorpionoides Vinson, 1863

Araneidae sp. indet.

Araneus apricus (Karsch, 1884)

Araneus sp. 2

Araniella sp. ?

Argiope aurocincta Pocock, 1898

A. australis (Walckenaer, 1805)

A. levii Björn, 1997

A. trifasciata (Forskål, 1775)

Caerostris sexcuspidata (Fabricius, 1793)

C. vicina (Blackwall, 1866)

Chorizopes sp. 1

Chorizopes sp. 2

Cyclosa insulana (Costa, 1834)

Cyphalonotus larvatus (Simon, 1881)

Cyrtophora citricola (Forskål, 1775)

Gasteracantha milvoides Butler, 1873

Gea infuscata Tullgren, 1910

Hypsosinga lithyphantoides Caporiacco, 1947

Isoxya stuhlmanni (Bösenberg \& Lenz, 1894)

I. tabulata (Thorell, 1859)

Isoxya sp. 3

Kilima sp. imm.?

Lipocrea longissima (Simon, 1881)

Nemoscolus elongatus Lawrence, 1947

Neoscona blondeli (Simon, 1885)

N. hirta (C. L. Koch, 1845)

N. penicillipes (Karsch, 1879)

N. rufipalpis (Lucas, 1858)

N. subfusca (C. L. Koch, 1837)

N. theisi theisiella (Tullgren, 1910)

$N$. triangula (Keyserling, 1864)

Neoscona sp. 8

Pararaneus cyrtoscapus (Pocock, 1898)

Prasonica sp.

Singa sp. 1

Singa sp. 2
FWB $\quad$ FP, ST

RWB FF, FP

GW $\quad$ ST

OWB $\quad$ BW, ST

OWB BW, FP, RF, ST

OWB BW

OWB

OWB

OWB

OWB

OWB

OWB

OWB

OWB

OWB

HWB

HWB

OWB

OWB

OWB

OWB

OWB

OWB

OWB

OWB

OWB

OWB

OWB

OWB

OWB

OWB

OWB

OWB

OWB

OWB

OWB

OWB

OWB

OWB

OWB

OWB
AS, AX, FP, SF, ST

AS, FP, ST

AS, AX, FP, RF, SF, ST

BW, FP, ST

BW

AX, BW, FF, FP, RF, ST

FF, RF

FP, RF, ST

BW, FF, RF, ST

$\mathrm{AX}, \mathrm{RF}, \mathrm{ST}$

RF

AS, BW, FP, RF, SF, ST

AS, ST

AS, AX, BW, RF, ST

All habitats sampled

FP, RF

AS, AX, BW, ST

AS, BW, RF, ST

All habitats sampled

ST

AS

BW

AS

AS, FF, FP, SF, ST

RF, ST

RF, ST

BW, RF, ST

RF, SF

AS, RF, ST

AX, BW, RF, ST

BW

RF

FP

AS, RF, ST

AS 
FAMILY: CAPONIIDAE

Caponia chelifera Lessert, 1936

GW

AS, AX, BW, FF, RF, ST

FAMILY: CLUBIONIDAE

Clubiona abbajensis Strand, 1906

C. annuligera Lessert, 1929

C. bevisi Lessert, 1923

C. durbana Roewer, 1951

C. helva Simon, 1897

C. pupillaris Lawrence, 1938

C. pongolensis Lawrence, 1952

FAMILY: CORINNIDAE

Apochinomma formicaeforme Pavesi, 1881

Cambalida coriacea Simon, 1909

Castianeira sp.

Cetonana simoni (Lawrence, 1942)

C. tridentata Lessert, 1923

Cetonana sp. 3

Corinna natalis Pocock, 1898

Corinninae sp.

Corinnomma semiglabrum (Simon, 1896)

C. lawrencei Haddad, in press $\dagger$

Copa flavoplumosa Simon, 1885

Copa sp.†

Graptartia tropicalis Haddad, 2004

Hortipes aelurisiepae Bosselaers \& Jocqué, 2000

$H$. griswoldi Bosselaers \& Jocqué, 2000

Merenius alberti Lessert, 1923

Messapus martini Simon, 1898

Messapus sp. $\dagger$

Orthobula radiata Simon, 1897

Pronophaea natalica Simon, 1897

Thysanina transversa Lyle \& Haddad, in press $\dagger$

Trachelas schenkeli Lessert, 1923

Trachelas sp. 2

Trachelas sp. 3

Trachelas sp. 4

Trachelinae sp.o

FAMILY: CTENIDAE

Anahita sp.

Ctenus gulosus Des Arts, 1912?

FAMILY: CYATHOLIPIDAE

Cyatholipidae sp. indet.

FAMILY: CYRTAUCHENIIDAE

Ancylotrypa zebra Simon, 1892

Ancylotrypa sp. $2 \$$

FAMILY: DEINOPIDAE

Deinopis cylindrica Pocock, 1898

Deinopis sp. 2 imm.

Menneus camelus Pocock, 1902

FAMILY: DICTYNIDAE

Archaeodictyna sp. 1

Dictyna sp. 1

Dictyna sp. 2

Mashimo leleupi Lehtinen, 1967

FAMILY: ERESIDAE

Adonea sp.?

$\begin{array}{ll}\text { PWB } & \text { AX } \\ \text { PWG } & \text { BW } \\ \text { PWF } & \text { ST } \\ \text { PWF } & \text { RF, ST } \\ \text { PWB } & \text { AX, FF } \\ \text { PWF } & \text { RF } \\ \text { PWB } & \text { AX, FF }\end{array}$

PWF/GW AX, BW, ST

PWF AX, FF, FP, RF, SF, ST

GW AS, BW, FP, ST

PWB AX, FF, ST

PWB All habitats sampled

PWF AX, FF, ST

PWB AX, FF, ST

GW AX, FF

GW AS, BW, FP, RF, ST

GW AX, BW, FF, FP, RF, SF, ST

PWF RF

GW AX, BW, FF, RF, ST

GW AX, BW, FP, RF, SF, ST

GW AX, FP, RF

GW All habitats sampled

GW/PWB BW, SF

GW AX, RF, SF

GW AX, BW, FF, RF, ST

GW RF

PWF RF

PWF AX, FP, ST

PWB AX, FF, ST

PWB AX, BW, SF

PWB BW

GW BW, ST

GW

GW

BW, FP

FF

SWB RF

GW BW, RF

GW BW, RF, ST

MOWB BW, FP, RF, SF, ST

MOWB ST

MOWB BW, FP, ST

RWB AS, AX, BW, FP, ST

RWB AX, BW, RF, ST

RWB AS, ST

RWB AX, FP

RWB AS
GW BW, FP, RF 
Appendix 1 (continued)

Dresserus sp.

Gandanomeno sp.

Stegodyphus africanus Blackwall, 1866

S. mimosarum Pavesi, 1893

FAMILY: GNAPHOSIDAE

Asemesthes ceresicola Tucker, 1923?

Camillina cordifera (Tullgren, 1910)

C. corrugata (Purcell, 1907)

C. maun Platnick, 1987

Drassodes sp.

Echemus sp.

Echeminae sp. 1

Gnaphosinae sp. 1

Latonigena africanus Tucker, 1923

Megamyrmaekion sp. imm.

Micaria sp. 1

Micaria sp. 2

Poecilochroa capensis Strand, 1909?

Scotophaeus sp.?

Setaphis browni (Tucker, 1923)

Trachyzelotes jaxartensis (Kronenberg, 1875)

Xerophaeus bicarvus Tucker, 1923

X. zuluensis Lawrence, 1938

Xerophaeus sp. 3

Xerophaeus sp. 4

Zelotes bimamillatus (Caporiacco, 1941)

Z. lavus Tucker, 1923

Z. natalensis Tucker, 1923

Z. scrutatus (O. P.-Cambridge, 1872)

Z. tuckeri Roewer, 1951

Z. ungulus Tucker, 1923

Z. uquathus FitzPatrick, in litt. $\dagger$

Zelotes sp. 8

FAMILY: HAHNIIDAE

Hahnia lobata Bosmans, 1981?

FAMILY: HERSILIIDAE

Hersilia sericea Pocock, 1898

FAMILY: IDIOPIDAE

Idiops grandis (Hewitt, 1915)

Segregara mossambicus (Hewitt, 1919)

S. pectinipalpis (Purcell, 1903)

S. transvaalensis (Hewitt, 1913)

FAMILY: LINYPHIIDAE

Meioneta natalensis Jocqué, 1984

Microctenonyx sp.

FAMILY: LIOCRANIDAE

Rhaeboctesis sp.?

FAMILY: LYCOSIDAE

Allocosa lawrencei (Roewer, 1951)

Alopecosa sp.

Amblyothele sp.

Arctosa sp.

Evippomma squamulatum (Simon, 1898)

Hippasa australis Lawrence, 1927

Hogna sp.

Lycosa $\mathrm{sp}$.

Lycosidae sp.d
RWB

RWB

RWB

RWB

GW

GW

GW

GW

GW

PWB

GW

GW

PWF

PWF

GW

GW

GW

GW

GW

GW

GW

GW

PWB

GW

GW

GW

GW

GW

GW

GW

GW

GW

SWB

PWB

GW

GW

GW

GW

SWB

SWB

PWF

GW

GW

GW

GW

GW

FWB

GW

GW

GW
BW, ST

AS

BW

AS, AX, BW

AS, BW, ST

AS, AX, BW, FF, FP, RF, ST

$\mathrm{AX}, \mathrm{BW}, \mathrm{RF}$

ST

AS, RF

AX

BW

$\mathrm{AX}$

AS, AX

AS

AS, AX, BW, ST

$\mathrm{AX}, \mathrm{FF}$

AX, ST

BW, FP

FP, ST

AX

BW, ST

AX, BW

$\mathrm{AX}$

RF, ST

BW, FF, RF, ST

$\mathrm{AX}, \mathrm{RF}$

$\mathrm{RF}$

$\mathrm{BW}$

AX, BW, RF, ST

$\mathrm{BW}, \mathrm{RF}$

$\mathrm{AX}$

AX

ST

All habitats sampled

AS

BW, FP, ST

BW, FP

$\mathrm{BW}$

AS, RF, ST

AX, BW, ST

ST

AX, BW, RF, ST

AX, FP

AX, FF, ST

$\mathrm{FF}$

AS, BW, FF, RF

All habitats sampled

FF, FP

AX, BW

BW, ST 
Appendix 1 (continued)

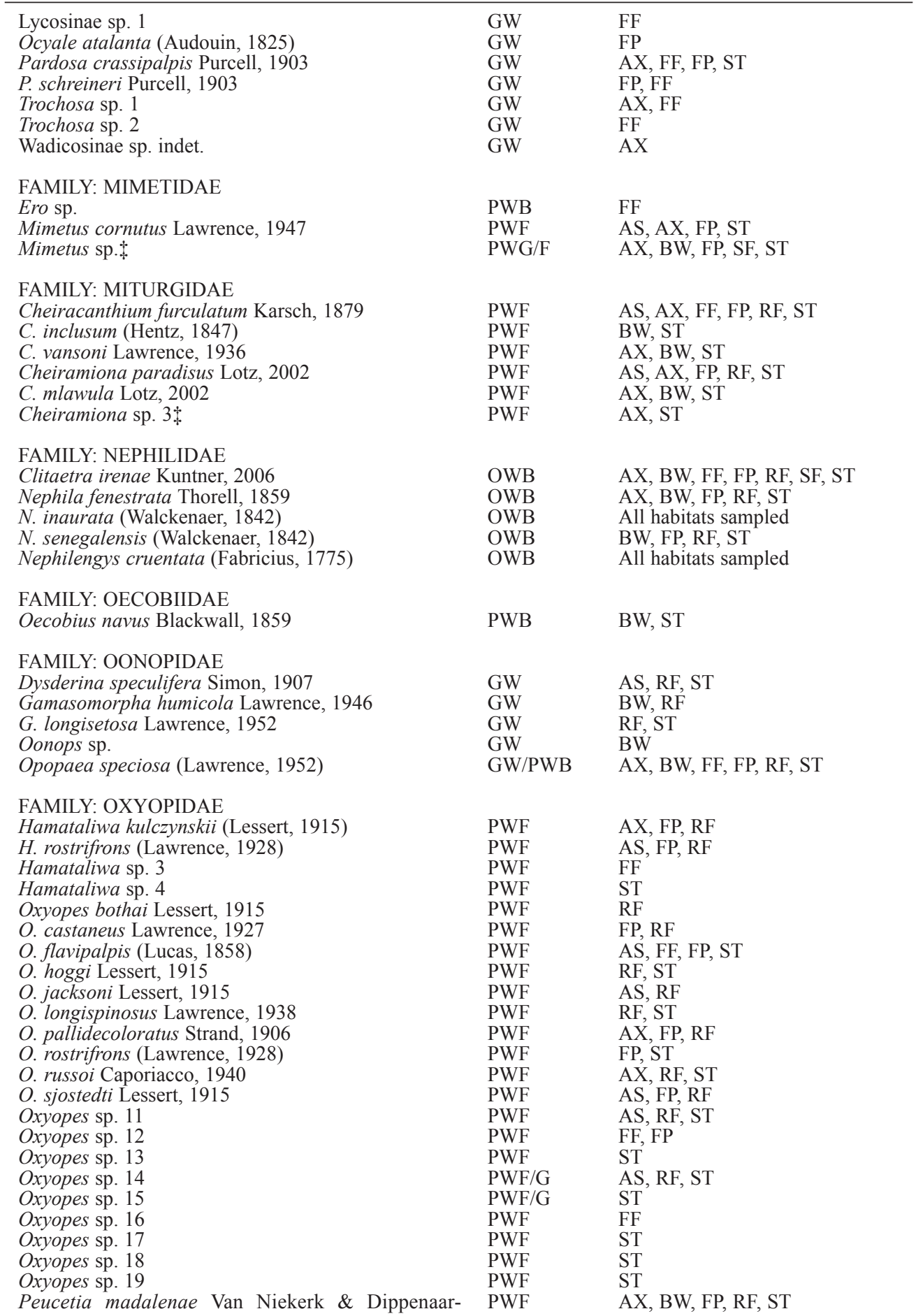

Schoeman, 1994 
Appendix 1 (continued)

FAMILY: PALPIMANIDAE

Palpimanus potteri Lawrence, 1937

P. transvaalicus Simon, 1893

FAMILY: PHILODROMIDAE

Ebo sp.

Gephyrota sp.\$

Philodromus browningi Lawrence, 1952

P. partitus Lessert, 1919

Suemus punctatus Lawrence, 1938

Tibellus hollidayi Lawrence, 1952

T. sunetae Van den Berg \& Dippenaar-Schoeman, 1994

FAMILY: PHOLCIDAE

Leptopholcus sp.\$

Smeringopus $\mathrm{sp} \notin$

Pehrforsskalia sp.?

FAMILY: PHYXELIDIDAE

Xeviosa amica Griswold, 1990

FAMILY: PISAURIDAE

Afropisaura rothiformis (Strand, 1908)

Charminus atomarius (Lawrence, 1942)

C. natalensis (Lawrence, 1947)

Cispius kimbius Blandin, 1978

Cispius sp. 2 \$

Euprosthenopsis vuattouxi Blandin, 1977

Maypacius bilineatus (Pavesi, 1895)

Perenethis simoni (Lessert, 1916)

Pisauridae sp. indet.

Rothus purpurissatus Simon, 1898

Thalassius margaritatus Pocock, 1898

T. spinosissimus (Karsch, 1879)

FAMILY: PRODIDOMIDAE

Prodidominae sp. indet.

Prodidomus flavipes Lawrence, 1952

Theuma fusca Purcell, 1907

T. maculata Purcell, 1907

T. tragardhi Lawrence, 1947

FAMILY: SALTICIDAE

Afromarengo coriacea (Simon, 1900)

Asemonea stella Wanless, 1980

Baryphas ahenus Simon, 1902

Bianor sp.

Cyrba boveyi Lessert, 1933

C. lineata Wanless, 1984

Dendryphantes sp.

Encymachus sp.?

Evarcha dotata (Peckham \& Peckham, 1903)

Evarcha sp. 2

Evarcha sp. 3

Evarcha sp. 4

Festucula festuculaeformis (Lessert, 1926)

Goleba puella (Simon, 1885)

Habrocestum sp.

Harmochirus luculentis (Simon, 1885)

Harmochirus sp. 2

Heliophanus claviger Simon, 1901

H. debilis Simon, 1901

H. orchesta Simon, 1885
GW

GW

PWF

PWF

PWB

PWF

PWF

$\mathrm{PWF} / \mathrm{G}$

PWF/G

SPWB

SPWB

SPWB

RWB

PWF

PWF

PWF

PWF

PWF

PWF

GW

PWF

PWF

PWF

GW/PWF

GW

GW

GW

GW

GW

GW

PWF

PWF

PWF/G

PWF

GW

GW

PWF

GW

PWF/G

PWF/G

PWG

PWF

PWF

PWF

GW

PWG

PWG

PWF

PWG

PWG
AS, AX, BW, RF, ST

AX, BW, FF, FP, ST

AS, BW, ST

AX, FP, RF, ST

AX, FF, FP, RF

AS, BW, RF, ST

AS, BW, ST

AS

AS, FP, ST

RF, SF, ST

AS, AX, BW, FF, FP, RF, ST

AS, BW

BW, FP, ST

AS, AX, BW, FP, RF, ST

BW, FP, ST

AX, FP, RF, ST

AS, AX, BW, FF, FP, ST

BW, ST

BW, ST

BW, RF

FP

BW, RF

AS, ST

FP, RF

AX, FP, RF

BW

AS, BW, ST

AS

BW, ST

BW, ST

BW, SF

FP, RF, SF, ST

AX, FP, ST

ST

BW

AS, BW, RF

AX, BW, ST

AX

AS, BW, ST

AS, FP, ST

$\mathrm{AS}, \mathrm{FF}$

ST

BW

FF, ST

ST

AS

AS

BW

AS, AX, RF

FP, RF 
Appendix 1 (continued)

\begin{tabular}{|c|c|c|}
\hline H. pauper Wesołowska, 1986 & PWG & AS, FP, RF \\
\hline Heliophanus sp. 5 & PWB & $\mathrm{AX}$ \\
\hline Hispo inermis (Caporiacco, 1947) & PWB & $\mathrm{BW}, \mathrm{SF}, \mathrm{ST}$ \\
\hline Holcolaetis zuluensis Lawrence, 1937 & PWF & $\mathrm{AS}, \mathrm{AX}, \mathrm{BW}, \mathrm{FF}, \mathrm{SF}, \mathrm{ST}$ \\
\hline Hyllus argyrotoxus Simon, 1902 & PWF & ST \\
\hline H. brevitarsis Simon, 1902 & PWF & $\mathrm{AS}, \mathrm{BW}, \mathrm{FP}, \mathrm{RF}, \mathrm{ST}$ \\
\hline H. treleaveni Peckham \& Peckham, 1902 & PWF & $\mathrm{BW}, \mathrm{FP}$ \\
\hline Hyllus sp. 4 & PWF & $\mathrm{FF}, \mathrm{ST}$ \\
\hline Kima variabilis Peckham \& Peckham, 1903 & PWF & BW, ST \\
\hline Menemerus manicus Wesolowska, 1999 & PWF & BW, RF \\
\hline Mexcala elegans Peckham \& Peckham, 1903 & GW/PWF & All habitats sampled \\
\hline Myrmarachne ichneumon (Simon, 1885) & PWF & BW, ST \\
\hline M. laurentina Bacelar, 1953 & PWF & $\mathrm{BW}$ \\
\hline M. uvira Wanless, 1982 & GW & AS, AX \\
\hline Myrmarachne sp. 4 & PWF & $\mathrm{RF}, \mathrm{ST}$ \\
\hline Myrmarachne sp. 5 & PWF & ST \\
\hline Natta horizontalis Karsch, 1879 & PWG & All habitats sampled \\
\hline Pachyballus castaneus Simon, 1900 & PWF & AX \\
\hline Pachypoessa sp. $\dagger$ & GW & AS \\
\hline Pellenes bulawayoensis Wesolowska, 2000 & GW & AS \\
\hline Pellenes sp. 2 & GW & RF \\
\hline Phlegra bresnieri (Lucas, 1846) & GW & $\mathrm{AS}, \mathrm{BW}$ \\
\hline P. nuda Próchniewicz \& Heciak, 1994 & GW & $\mathrm{AS}, \mathrm{AX}$ \\
\hline Phintella aequipes (Peckham \& Peckham, 1903) & PWF & FP \\
\hline Phintella sp. 2 & PWF & ST \\
\hline Portia schultzi Karsch, 1878 & PWF & $\mathrm{AS}, \mathrm{AX}, \mathrm{BW}, \mathrm{FF}, \mathrm{FP}, \mathrm{ST}$ \\
\hline Pseudicius sp. $1 \dagger$ & $\mathrm{PWB} / \mathrm{F}$ & $\mathrm{AX}, \mathrm{FF}, \mathrm{RF}, \mathrm{SF}, \mathrm{ST}$ \\
\hline Pseudicius sp. 2 & $\mathrm{PWB} / \mathrm{F}$ & $\mathrm{AX}, \mathrm{FF}, \mathrm{FP}$ \\
\hline Pseudicius sp. 3 & PWF & AS \\
\hline Schenkelia modesta Lessert, 1927 & PWF & $\mathrm{FF}$ \\
\hline Siler sp. & GW & $\mathrm{AX}, \mathrm{FP}$ \\
\hline Sonoita lightfooti Peckham \& Peckham, 1903 & PWF & $\mathrm{FP}, \mathrm{RF}, \mathrm{ST}$ \\
\hline Stenaelurillus sp. $1 \dagger$ & GW & $\mathrm{AS}, \mathrm{BW}, \mathrm{ST}$ \\
\hline Stenaelurillus sp. 2 & GW & ST \\
\hline Thyene bucculenta (Gerstäcker, 1873) & PWF & ST \\
\hline T. coccineovittata (Simon, 1885) & PWG & RF, ST \\
\hline T. crudelis Peckham \& Peckham 1903 & PWF & $\mathrm{AS}, \mathrm{AX}, \mathrm{BW}, \mathrm{FF}$ \\
\hline T. inflata (Gerstaecker, 1873) & PWF & $\mathrm{AX}, \mathrm{BW}, \mathrm{FP}, \mathrm{ST}$ \\
\hline T. natali Peckham \& Peckham, 1903 & PWF & $\mathrm{AX}, \mathrm{BW}, \mathrm{FF}, \mathrm{RF}, \mathrm{ST}$ \\
\hline T. ogdeni Peckham \& Peckham, 1903? & PWF & RF \\
\hline T. semiargentea (Simon, 1884) & $\mathrm{PWF} / \mathrm{G}$ & AS, ST \\
\hline Thyene sp. $8 ?$ & PWG & $\mathrm{ST}$ \\
\hline Thyenula aurantiaca (Simon, 1902) & PWG & $\mathrm{AS}, \mathrm{RF}$ \\
\hline T. ogdeni Peckham \& Peckham, 1903 & PWG & RF, ST \\
\hline Tomocyrba sp. $\dagger$ & PWF & $\mathrm{FF}$ \\
\hline Tusitala barbata Peckham \& Peckham, 1902 & PWF & $\mathrm{AS}, \mathrm{BW}, \mathrm{ST}$ \\
\hline Tusitala sp. 2 & PWF & FF \\
\hline Veissela durbani (Peckham \& Peckham, 1903) & PWF & ST \\
\hline Viciria morrigera Peckham \& Peckham, 1903 & PWF & $\mathrm{BW}, \mathrm{FF}$ \\
\hline V. mustela Simon, 1902 & $\mathrm{PWF} / \mathrm{G}$ & AS, ST \\
\hline Viciria sp. 3 & PWF & RF, ST \\
\hline Salticidae sp. 1 & PWG & AS \\
\hline Salticidae sp. 2 & PWB & $\mathrm{AX}$ \\
\hline Salticidae sp. 3 & PWF & $\mathrm{ST}$ \\
\hline Salticidae sp. 4 & PWF & FP \\
\hline Salticidae sp. 5 & PWB & BW \\
\hline Salticidae sp. 6 & PWF & ST \\
\hline Salticidae sp. 7 & PWF & ST \\
\hline Salticidae sp. 8 & PWF & ST \\
\hline Salticidae sp. 9 & GW & AS \\
\hline Salticidae sp. 10 & PWF & $\mathrm{BW}, \mathrm{ST}$ \\
\hline Salticidae sp. 11 & GW & FP \\
\hline $\begin{array}{l}\text { FAMILY: SCYTODIDAE } \\
\text { Scytodes caffra Purcell, } 1904\end{array}$ & GW & All habitats sampled \\
\hline
\end{tabular}


Appendix 1 (continued)

S. maritima Lawrence, 1938

S. rubra Lawrence, 1937

FAMILY: SEGESTRIIDAE

Ariadna corticola Lawrence, 1952

Ariadna sp. 2

FAMILY: SELENOPIDAE

Anyphops barbertonensis (Lawrence, 1940)

Selenops zuluanus Lawrence, 1940

FAMILY: SICARIIDAE

Loxoscelis spinulosa Purcell, 1904

FAMILY: SPARASSIDAE

Olios auricornis (Simon, 1880)

O. chelifer Lawrence, 1937 ?

O. chubbi Lessert, 1925

O. correvoni Lessert, 1921

O. machadoi Lawrence, 1938

Olios sp. 6

Palystes superciliosus L. Koch, 1875

Panaretella immaculata Lawrence, 1952

P. zuluana Lawrence, 1937

Pseudomicrommata longipes (Bösenberg \& Lenz, 1895)

FAMILY: SYMPHYTOGNATHIDAE

Patu sp.

FAMILY: TETRAGNATHIDAE

Leucauge decorata (Blackwall, 1864)

L. medjensis Lessert, 1930

Tetragnatha ceylonica Cambridge, 1869

T. demissa L. Koch, 1872

T. maxillosa Thorell, 1895

T. subsquamata Okuma, 1985

T. unicornis Tullgren, 1910

Tetragnatha sp. $6+$

FAMILY: THERAPHOSIDAE

Brachionopus sp.

Ceratogyrus bechuanicus Purcell, 1902

Harpactira sp.

Idiothele $\mathrm{sp} \$$

FAMILY: THERIDIIDAE

Achaearanea sp.

Anelosimus sp.

Argyrodes affinis (Lessert, 1936)

A. convivans Lawrence, 1937

Argyrodes sp. 3

Argyrodes sp. 4

Argyrodes sp. 5

Choriozopella tragardi Lawrence, 1947

Dipoena sp.

Episinus bilineatus Simon, 1894

Euryopis sp. 1

Euryopis sp. 2

Latrodectus cinctus Blackwall, 1865

L. geometricus C. L. Koch, 1841

L. renivulvatus Dahl, 1902

Phoroncidia eburnea (Simon, 1895)

Steatoda lawrencei Brignoli, 1983

$\begin{array}{ll}\text { GW } & \text { AX, FP, RF } \\ \text { GW } & \text { AX, FF } \\ & \\ \text { RWB } & \text { AS, AX, RF } \\ \text { RWB } & \text { AS }\end{array}$

PWB/GW AS, AX, BW, FF, RF, ST

GW AS, ST

GW AS, BW, RF, SF, ST

PWB AX, FP

PWF RF

PWF RF, ST

PWB AS, AX, BW

PWF AX, BW, FP

PWB AX, FF

PWF BW, RF, ST

PWB RF, ST

PWF AX, BW

PWG BW, FP

OWB

AS, AX, BW

OWB

OWB

OWB

OWB

OWB

OWB

OWB

OWB

FP, ST

All habitats sampled

ST

ST

AX, BW, FP

FP, RF, ST

$\mathrm{AX}$

FP

GW

GW

GW

GW

All habitats sampled

BW, SF

AS, BW

BW, RF

GWB

GWB

GWB

GWB

GWB

GWB

GWB

GWB

GWB

GWB

GWB

GWB

GWB

GWB

GWB

GWB

GWB
FP, RF

FP, RF

AX, FP, RF, ST

All habitats sampled

AS

AS

FF, FP, RF

$\mathrm{AX}$

AS, AX, FF, ST

AS, ST

AS, AX, FF, FP, ST

AX, FP

BW, ST

AS, BW, FP

BW, FF, FP

AX, RF, ST

AS, AX, FP, RF, ST 
Appendix 1 (continued)

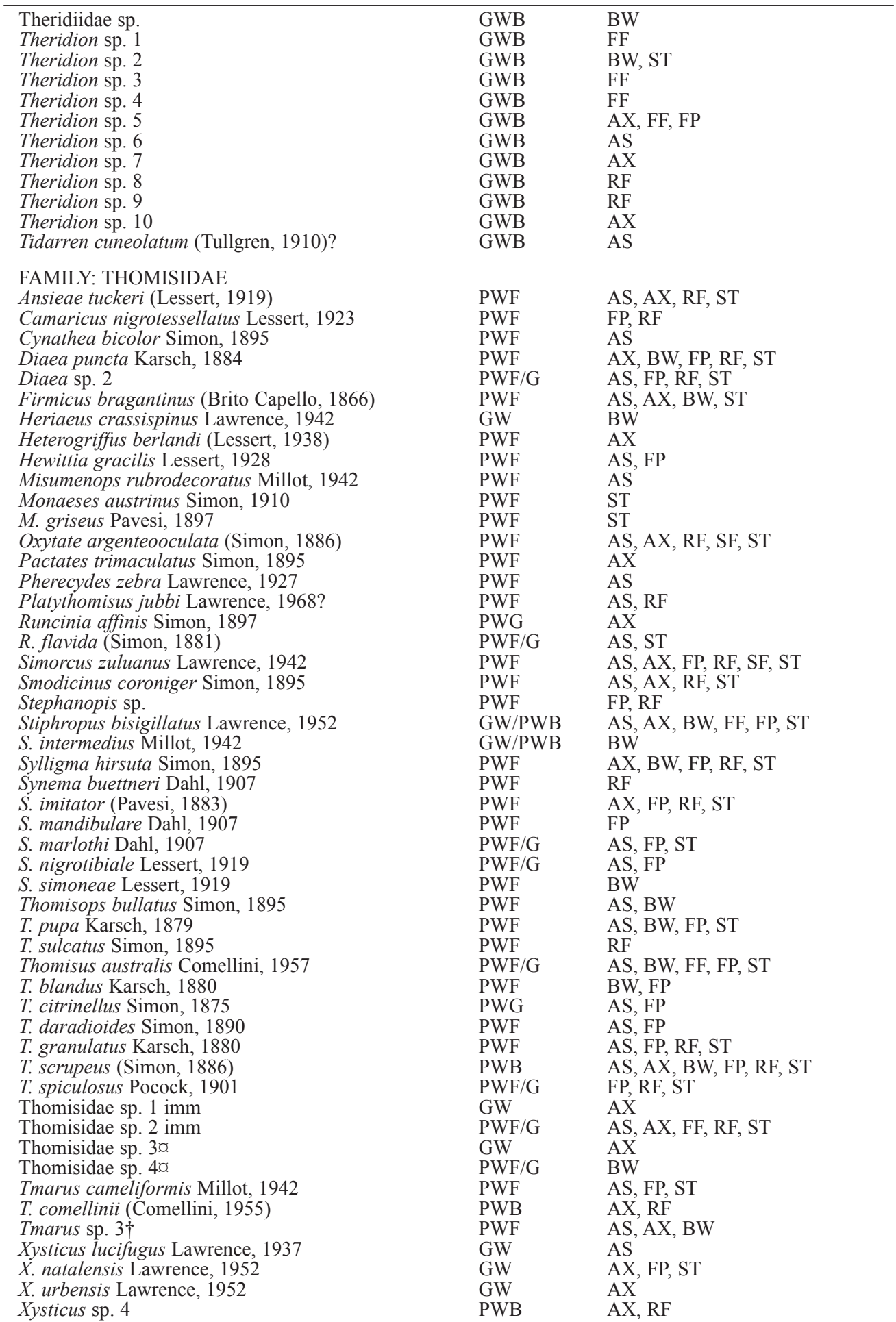


Appendix 1 (continued)

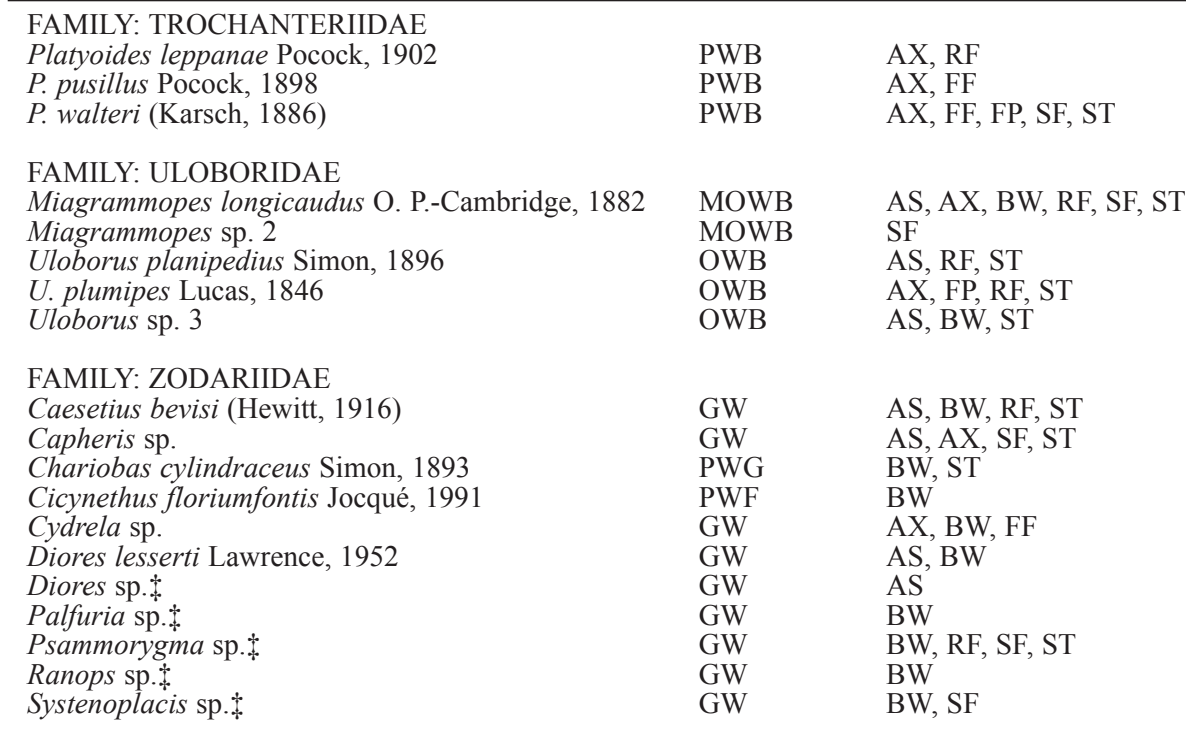

ORDER: OPILIONES (harvestmen)

FAMILY: BIANTIDAE

Metabiantes maximus Lawrence, 1931

GW All habitats sampled

FAMILY: PHALANGIIDAE

Rhampsinitus leighi (Pocock, 1902) GW AX, FF, FP, RF, SF

Rhampsinitus $\mathrm{sp} .2$

GW FF, FP, SF

ORDER: PSEUDOSCORPIONES (false scorpions)

FAMILY: ATEMNIDAE

Atemnidae sp.

Cyclatemnus dolosus Beier, 1958

C. globosus parvus Beier, 1964

Titanatemnus natalensis Beier, 1932

$\begin{array}{ll}\text { PWB } & \text { AX } \\ \text { PWB } & \text { AX, FF } \\ \text { PWB } & \text { AX } \\ \text { PWB } & \text { AX, BW, FF, FP, SF } \\ & \\ \text { PWB/GW } & \text { AX, FF } \\ \text { GW } & \text { FF, SF, ST } \\ \text { PWB } & \text { BW } \\ & \\ \text { GW } & \text { AX, ST } \\ & \\ \text { PWB/G } & \text { BW } \\ \text { GW } & \text { BW, ST } \\ & \\ \text { GW/PWB } & \text { AX, ST }\end{array}$

FAMILY: CHEIRIDIIDAE

Cheiridium sp.

Cryptocheiridium subtropicum Tullgren, 1907

FAMILY: CHELIFERIDAE

Lophochernes mucronatus (Tullgren, 1907)

$\mathrm{AX}, \mathrm{ST}$

FAMILY: GEOGARYPIDAE

Geogarypus sp.

GW

FAMILY: OLPIIDAE

Nanolpium milanganum Beier, 1964

Olpiidae sp.

$\begin{array}{ll}\text { GW } & \text { BW, ST } \\ \text { GW/PWB } & \text { AX, ST }\end{array}$

FAMILY: WITHIIDAE

Withius sp.

FAMILY: BUTHIDAE

Pseudolychas pegleri (Purcell, 1901)

Uroplectes formosus formosus Pocock, 1890

$\mathrm{PWB} / \mathrm{GW}$

$\mathrm{PWB} / \mathrm{GW}$
AX, BW, RF

AX, FF, FP, RF 
Appendix 1 (continued)

\begin{tabular}{|c|c|c|}
\hline $\begin{array}{l}\text { U. f. maculipes Hewitt, } 1918 \\
\text { U. olivaceus } \text { Pocock, } 1896\end{array}$ & $\begin{array}{l}\mathrm{GW} \\
\mathrm{GW}\end{array}$ & $\begin{array}{l}\text { AX, BW } \\
\text { AS, AX, BW, FF, SF, ST }\end{array}$ \\
\hline $\begin{array}{l}\text { FAMILY: LIOCHELIDAE } \\
\text { Cheloctonus jonesii Pocock, } 1892 \\
\text { Opisthacanthus asper (Peters, 1861) } \\
\text { O. validus (Thorell, 1976) }\end{array}$ & $\begin{array}{l}\text { GW/PWB } \\
\text { GW/PWB } \\
\text { GW }\end{array}$ & $\begin{array}{l}\text { AS, BW, FP, RB, SF, ST } \\
\text { AS, AX, BW, SF, ST } \\
\text { AS, BW }\end{array}$ \\
\hline $\begin{array}{l}\text { FAMILY: SCORPIONIDAE } \\
\text { Opistophthalmus glabrifrons } \text { Peters, } 1861\end{array}$ & PWB & BW \\
\hline \multicolumn{3}{|c|}{ ORDER: SOLIFUGAE (sun-spiders) } \\
\hline $\begin{array}{l}\text { FAMILY: SOLPUGIDAE } \\
\text { Solpuga zuluana Lawrence, } 1937 ? \\
\text { Solpugema krugeri Lawrence, 1964? }\end{array}$ & $\begin{array}{l}\text { GW } \\
\text { GW }\end{array}$ & $\begin{array}{l}\text { AX, AS, BW, ST } \\
\text { BW }\end{array}$ \\
\hline
\end{tabular}

